R. S. G. writes: "As a teacher he was unusually attractive because of the peculiarly earnest and confidential manner in which he imparted his information or advice... The student had a sense of privilege in listening to what he had to say."

D. W. writes: "I think that in his work the qualities I would stress were essential honesty and dislike of all humbug and pretence. A day with Bell Jones in his hospital was as exciting as it was exhausting: starting early in the morning, he would finish at about 9 p.m. and then nothing would delight him more than to sit chatting far into the night. He was at his best on these informal occasions when the conversation would range from the latest orthopaedic venture on spine, or hip, or what you will, to fishing, sailing or medical politics: the whole interspersed and illustrated vividly with tales of the Australian backwoods or the Suffolk countryside."

The Lord Bishop of St Edmundsbury and Ipswich, the Rt. Rev. Harold Morris, D.D., in his address at the memorial service on May 20, said: "Today, at this service, we have met to pay honour to Edward Bell Jones, a great orthopaedic surgeon who brought honour and distinction to his profession and to the town of Ipswich and county of Suffolk where he worked with the greatest devotion for twenty-two years. I count it a privilege in the name of all here present to be called upon to pay a tribute of gratitude and affection to him. When I was gathering impressions about his character a great friend and close colleague described him as a man of great tenacity, who stuck to his guns and worried till he achieved his purposea very hard worker of whom it could be said that he gave his life for others and wore himself out in the service of his fellow men. He gave his life for others as certainly as the man who dies on the field of battle in the service of his friends; and we are all the poorer because Bell Jones has been taken from us."

It would be a bold and foolish man who tried to improve on these words. In all of them the same theme can be discerned, and the question why he so combined a love of perfection, a devotion to realism, an affection for his fellow men and an intense burning desire to do good, intrigued me. The answer lies in a sentence of a letter from his widow Jocelyn. "His first love was Art, second the Church, but he decided Medicine was the best after all." So now I know why so many different people felt so similarly about Bell Jones, and why we remember so clearly his warm heart, his sure touch, his keen discrimination and his vitality so intense that it was exciting to know him. He was an artist dedicated spiritually to a profession.

B. L. MCF.

\title{
THOMAS LABATT LAWSON
}

1913-1959

Mr T. L. Lawson, consulting orthopaedic surgeon to the Beckett Hospital, Barnsley, and to the King Edward VII Orthopaedic Hospital, Sheffield, died suddenly at his home at Worsborough Dale, Barnsley, on May 14, at the age of forty-six.

Thomas Labatt Lawson was born in Dublin of Irish Huguenot parents. He was educated at Trinity College, Dublin, graduating B.A. in philosophy in 1937 and M.B., B.Ch., B.A.O. in 1938. In 1940 he took the D.T.M. \& H. (Liverpool), and in 1945 the F.R.C.S. (Edinburgh) and the M.Chir. (Dublin). After holding several house appointments he entered the Colonial Medical Service and served as a medical officer in Uganda. He was then appointed to Nigeria 
and became lecturer in othopaedic surgery at University College. Ibadan. He was largely responsible for the organisation of the orthopaedic services in Nigeria, and the development of orthopaedic surgery in that country is in great measure due to his energy, tact and skill. Those who visited him in Nigeria were greatly impressed by his work in difficult circumstances. Nine years ago he was invalided out of the Service and returned to Britain, where he was appointed consultant orthopaedic surgeon to the Beckett Hospital, Barnsley, and to the King Edward VII Orthopaedic Hospital, Sheffield. At Barnsley he devoted his great energy and ability to the development of a comprehensive accident and orthopaedic service. The excellence of this department will be a lasting memorial. He was a member of the British Orthopaedic Association and a much loved member of the Yorkshire Orthopaedic Club.

Tom Lawson was a delightful man, full of Irish charm and wit and with great ability. $\mathrm{He}$ had wide interests, and was particularly fond of sailing and of all country pursuits. His colleagues in South Yorkshire had the greatest

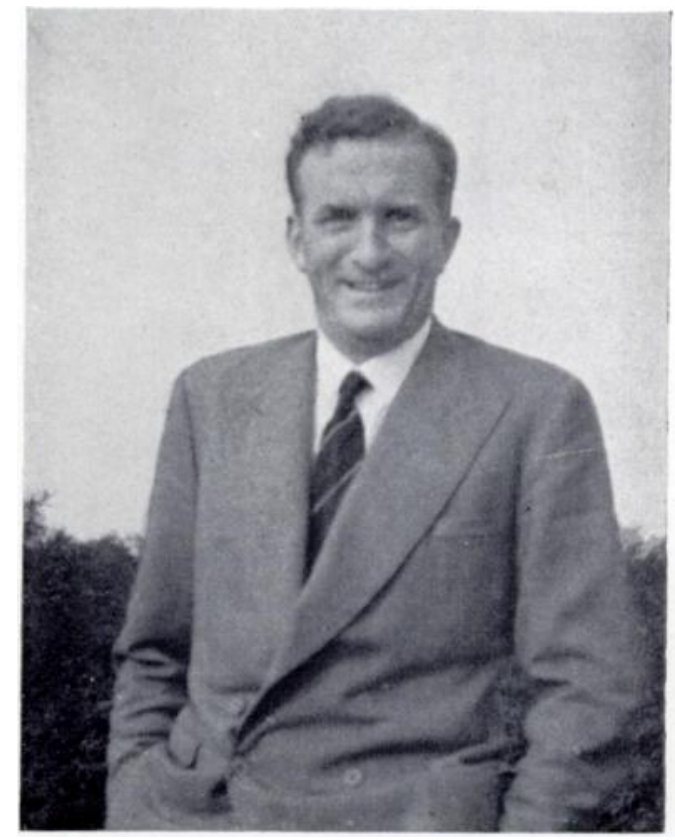
affection and respect for him. His patients adored him. We all grieve at the loss of a devoted surgeon and loyal friend, and extend our sympathy to his widow and his two daughters.

F. W. H.

\section{LENNOX GRAHAM TEECE}

1889-1959

All members of the Australian Orthopaedic Association were shocked to read in the press of the sudden death in his sleep of Mr Lennox Graham Teece while touring in France with his wife.

He had not been very fit for some years and consequently had given up skiing and golfing, but he continued to enjoy the races. I met him over twenty-five years ago while on a skiing holiday at Mount Kosciusko with the Australian Ski Club. Lennox, one of the senior members. was at that time a great leader of touring parties on the Main Range of the Australian Alps. His tall athletic figure was invariably in the lead, and the pace set was one which even beginners could follow. He learned his skiing in the days before the Aarlberg technique became popular. and no one at that time could execute a nicer telemark turn. Apart from his tirelessness he was so considerate of young inexpert tourists that each trip was a great success and enjoyed by all. During his winter holidays in Australia, and on occasion in New Zealand, he came in for much work in treating the injuries of this sport. This he did with efficiency and charm. He was a keen member of the club in evenings at bridge or poker, which he played very well. As an after-dinner speaker he was without a peer, not only in the ski club, but in the Australian Orthopaedic Association. With all his qualities it is natural that we remember his period of presidency as one of the most successful.

Vol. 41 B, No. 3, AUguSt 1959 